\title{
KECERNAAN BAHAN KERING, BAHAN ORGANIK, LEMAK KASAR DAN TOTAL DIGESTIBLE NUTRIENTS BERBAGAI HIJAUAN SECARA IN VITRO
}

\author{
IN VITRO DIGESTIBILITY OF DRY AND ORGANIC MATTER, ETHER EXTRACT AND \\ TOTAL DIGESTIBLE NUTRIENTS OF VARIOUS FORAGES
}

\author{
Farah Faradilla*1, Limbang Kustiawan Nuswantara ${ }^{1}$, Marry Christiyanto ${ }^{1}$ dan Eko \\ Pangestu ${ }^{1}$ \\ Laboratorium Ilmu Nutrisi dan Pakan \\ Fakultas Peternakan dan Pertanian Universitas Diponegoro, Semarang. \\ J1. Prof. H. Soedarto, S.H - Tembalang Semarang, Indonesia 50275 \\ *Corresponding author : farahdilla26.fd@gmail.com \\ Diterima: 12 Desember 2019, Direvisi: 30 Desember 2019, Disetujui: 20 Januari 2019
}

\begin{abstract}
ABSTRAK
Penelitian ini bertujuan untuk mengetahui kecernaan bahan kering, bahan organik, lemak kasar dan Total Digestible Nutrients (TDN) beberapa hijauan secara in vitro. Penelitian ini dilaksanakan pada bulan September 2018 - Januari 2019 di Laboratorium Ilmu Nutrisi dan Pakan, Fakultas Peternakan dan Pertanian, Universitas Diponegoro, Semarang. Penelitian ini menggunakan rancangan acak lengkap (RAL) dengan 8 jenis hijauan pakan sebagai perlakuan masing-masing 3 ulangan. Parameter yang diamati kecernaan bahan kering, bahan organik, lemak kasar dan TDN. Hasil penelitian menunjukkan bahwa berbagai jenis hijauan menghasilkan nilai kecernaan dan TDN yang berbeda $(\mathrm{P}<0,05)$. Kesimpulan hasil penelitian ini adalah kecernaan bahan kering, bahan organik dan lemak kasar dipengaruhi oleh kandungan nutrien dalam bahan pakan, sedangkan nilai TDN berkorelasi dengan nilai kecernaan nutrien dalam bahan pakan.
\end{abstract}

Kata kunci : Hijauan, In vitro, Kecernaan, dan TDN.

\begin{abstract}
ABSTRACK
This study aimed to determine in vitro digestibility of dry and organic matter, extract ether and Total Digestible Nutrients (TDN) of various forages. This study was conducted in September 2018 - January 2019 at the Laboratory of Nutrition and Feed Sciences, Faculty of Animal Husbandry and Agriculture, Diponegoro University, Semarang, using a completely randomized design (CRD) with 8 various of forage as treatment with 3 replications. Parameters observed were dry and organic matter digestibility, ether extract and TDN. The results showed that various forages had a significant effect $(P<0.05)$ on digestibility and TDN. It was concluded that the digestibility of dry and organic matter, and ether extract was influenced by nutrient content in feed ingredients, while TDN value correlates with the digestibility value of nutrients in feed ingredients.
\end{abstract}

Keywords : Forage, Digestibility, In vitro, and TDN. 


\section{PENDAHULUAN}

Pemeliharaan ternak khususnya ruminansia perlu adanya pakan yang mencukupi untuk menunjang pertumbuhan serta perkembangan dari ternak. Beberapa jenis tanaman masih digunakan untuk kebutuhan manusia, serta beberapa tanaman memiliki anti nutrisi. Pakan yang berserat merupakan bahan bahan yang banyak terdapat pada tanaman pakan (Christiyanto dan Subrata, 2005). Pemberian pakan tunggal rumput belum mampu memenuhi kebutuhan nutrien baik bagi mikroba rumen maupun ternak itu sendiri, sehingga masih dibutuhkan bahan pakan lain sebagai pelengkap (Christiyanto, 2005). Leguminosa merupa-kan jenis hijauan yang sering dimanfaat-kan untuk memenuhi kebutuhan hijauan pada kambing. Leguminosa memiliki kandungan protein kasar (PK), serat kasar (SK), dan bahan eter tanpa nitrogen (BETN) dan kandungan serat kasar (SK). Nilai total digestible nutrients (TDN) diperoleh dari hasil penjumlahan kecernaan dari proporsi serat kasar, protein kasar, ekstrak tanpa nitrogen dan ekstrak eter (Mastopan et al., 2015). Kecernaan pakan merupakan indikator penting yang dapat digunakan sebagai pedoman untuk menentukan jumlahnya nutrisi dan pakan yang dapat diserap oleh saluran pencernaan (Mayulu et al., 2018). In vitro salah satu teknik evaluasi pakan menggunakan rumen sebagai media fermentasi dan bantuan tabung fermentor yang dikondisikan mirip dengan keadaan di dalam rumen ternak (Makkar, 2004). Kelebihan in vitro adalah degradasi serta fermentasi pakan yang terjadi di dalam rumen dapat diukur dengan cepat dalam waktu singkat, biaya murah, dapat mengevaluasi dengan jumlah sampel yang banyak dan dapat terkontrol kondisinya (Indrayani et al., 2015). Tujuan penelitian adalah mengetahui kecernaan bahan kering, bahan organik, lemak kasar dan TDN berbagai hijauan secara in vitro.

\section{METODE PENELITIAN}

Penelitian dilaksanakan pada September 2018 - Januari 2019 di Laboratorium Ilmu Nutrisi Ternak, Fakultas Peternakan dan Pertanian, Universitas Diponegoro, Semarang. Alat yang digunakan adalah tabung reaksi, water bath, termometer, sentrrifuge, pipet, kompor listrik, beaker glass $250 \mathrm{ml}$, gelas ukur $50 \mathrm{ml}$, gelas ukur $25 \mathrm{ml}$, Goch Crusibel (porositas 1), pompa vakum, oven, timbangan analitik, eksikator, pinset, batang pengaduk, buchner, kertas saring bebas abu dan kertas minyak.

Materi yang digunakan dalam penelitian adalah hijauan yang terdiri dari daun mangga, pisang, nangka, mahoni, lamtoro, turi, gamal dan kaliandra. Cairan rumen yang digunakan adalah cairan rumen yang berasal dari kambing Peranakan Etawa yang berfistula yang diberi ransum standar yaitu dengan komposisi nutrien ransum PK 12,23\%, TDN $62,32 \%$ dan NDF 54,22\%. Reagensia yang digunakan adalah larutan Mc dougall dengan $\mathrm{pH}$ 6,5 - 6,8, larutan pepsin $\mathrm{HCl} 0,2 \%$ dan Aquades.

\section{Tahap Persiapan Cairan Rumen dan Bahan Pakan}

Kambing PE berfistula diberi pakan ransum sesuai kebutuhan selama satu minggu dengan komposisi nutrien ransum. Bahan pakan yaitu daun mangga, pisang, nangka, mahoni, lamtoro, turi gamal dan kaliandra yang disamakan ukuran partikelnya dengan pengayakan. Hijaun terlebih dahulu dilakukan analisis proksimat dengan hasil yang ditampilkan pada Tabel 1.

\section{Tahap Pencernaan In Vitro}

Pencernaan in vitro dilakukan dengan metode Tilley dan Terry (1963) dengan dua tahap pencernaan yaitu penceernaan fermentatif secara anaerob 
dan pencernaan secara enzimatis dengan pepsin $\mathrm{HCl}$.

\section{Analisis}

Analisis yang dilakukan untuk menghitung kecernaan bahan kering, kecernaan bahan organik, kecernaan lemak kasar dan TDN yang digunakan residu pakan yang telah dilakukan pencernaan secara in vitro Tilley dan Terry (1963). Perhitungan TDN menggunakan rumus Tilman et al. (1988).
Data yang diperoleh pada penelitian ini dianalisis dengan analisis sidik ragam (analysis of variance / ANOVA) menggunakan rancangan acak lengkap (RAL) yang terdiri dari 6 perlakuan bahan pakan dengan 3 kali ulangan. Apabila diperoleh perlakuan berbeda nyata maka akan dilakukan uji lanjutan menggunakan Duncan's Multiple Range Test (DMRT).

Tabel 1.

Kandungan Nutrisi dan Komponen Serat Hijauan

\begin{tabular}{lrrrrrrrr}
\hline \multirow{2}{*}{ Kandungan Nutrien } & \multicolumn{7}{c}{ Bahan Perlakuan } \\
\cline { 2 - 9 } & \multicolumn{1}{c}{ T1 } & \multicolumn{1}{c}{ T2 } & \multicolumn{1}{c}{ T3 } & \multicolumn{1}{c}{ T4 } & \multicolumn{1}{c}{ T5 } & \multicolumn{1}{c}{ T6 } & T7 & T8 \\
\hline & & $-\ldots$ & $-\ldots$ \\
BK & 92,28 & 90,74 & 91,73 & 90,02 & 91,64 & 91,08 & 92,02 & 91,81 \\
BO & 93,73 & 94,03 & 93,91 & 96,28 & 96,12 & 96,27 & 96,11 & 96,27 \\
PK & 8,99 & 15,52 & 15,51 & 12,71 & 32,03 & 27,63 & 25,39 & 25,97 \\
LK & 1,54 & 2,36 & 4,80 & 2,07 & 2,67 & 3,84 & 3,97 & 0,81 \\
BETN & 34,74 & 21,16 & 18,88 & 46,38 & 40,98 & 41,31 & 22,41 & 35,11 \\
SK & 48,46 & 54,99 & 54,72 & 35,12 & 20,44 & 23,49 & 44,34 & 34,38 \\
Karbohidrat & 83,20 & 76,15 & 73,60 & 81,50 & 61,42 & 64,80 & 66,75 & 69,49 \\
Isi Sel & 52,27 & 70,26 & 53,12 & 60,77 & 66,57 & 54,66 & 62,13 & 48,82 \\
NDF & 47,73 & 29,74 & 46,88 & 39,23 & 33,43 & 45,34 & 37,87 & 51,18 \\
ADF & 44,05 & 19,25 & 31,21 & 31,30 & 23,03 & 29,27 & 25,01 & 38,73 \\
NFC & 35,47 & 46,41 & 26,72 & 42,27 & 27,99 & 19,46 & 28,88 & 18,31 \\
Hemiselulosa & 3,68 & 10,49 & 15,37 & 7,93 & 10,40 & 16,07 & 12,86 & 12,45 \\
Selulosa & 14,62 & 2,33 & 4,34 & 12,86 & 18,05 & 9,21 & 17,33 & 25,78 \\
Lignin & 29,43 & 16,92 & 27,17 & 18,44 & 4,98 & 20,06 & 7,68 & 12,95 \\
Silika & 8,14 & 4,66 & 2,46 & 0,15 & 3,57 & 1,14 & 0,13 & 3,56 \\
Tanin & 20,43 & 7,75 & 1,48 & 29,37 & 9,27 & 6,60 & 11,79 & 3,07 \\
Abu & 11,20 & 10,63 & 10,24 & 10,34 & 10,73 & 9,17 & 11,66 & 8,56 \\
TDN & 67,07 & 68,55 & 55,40 & 74,80 & 57,65 & 75,92 & 51,26 & 46,18 \\
\hline Sumberyyyyyyyyyyyyyyy
\end{tabular}

Sumber: Data Analisis Laboratorium Ilmu Nutrisi dan Pakan, (2019).

\section{HASIL DAN PEMBAHASAN \\ Kecernaan Bahan Kering (KcBK)}

Hasil analisis ragam pada berbagai hijauan berbeda nyata $(\mathrm{p}<0,05)$ terhadap nilai KcBK. Nilai KcBK yang berbeda karena jenis hijauan dan kandungan nutrisi yang berbeda. Paramita et al. (2008) menyatakan faktor yang mempengaruhi nilai kecernaan adalah jumlah serta kandungan nutrien yang dikonsumsi 
ternak. Uji Duncan menunjukkan nilai KcBK daun turi (T6) dan daun mahoni (T4) tidak menunjukkan adanya perbedaan. Sedangkan pada daun kaliandra (T8) lebih rendah $(\mathrm{p}<0,05)$ dibandingkan dengan $\mathrm{T} 1, \mathrm{~T} 2, \mathrm{~T} 4, \mathrm{~T} 5$ dan T6, tetapi tidak berbeda nyata dengan daun pisang (T3) dan daun gamal (T7).

Pengaruh perlakuan nilai $\mathrm{KcBK}$ berbeda-beda, karena jenis hijauan dan kandungan nutrisi yang berbeda-beda. Paramita et al. (2008) menyatakan faktor yang mempengaruhi nilai kecernaan adalah kandungan kimia maupun fisik bahan pakan dan kondisi ternak seperti kondisi mikrobia dalam rumen. Daun turi memiliki rata-rata nilai $\mathrm{KcBK}$ yang tinggi yaitu $78,81 \%$ (Tabel 2) dibandingkan dengan hijauan lainnya. Faktor dari nilai $\mathrm{KcBK}$ daun turi tinggi karena salah satu komponen serat yaitu hemiselulosa yang tinggi. Purbajanti et al. (2011) menyatakan di dalam serat terdapat komponen yang mudah dicerna oleh mikrobia rumen, yang nantinya akan dimanfaatkan sebagai sumber energi. Nilai KcBK pada daun mahoni tinggi dibandingkan daun mangga, daun nangka, daun pisang, daun lamtoro, daun gamal dan daun kaliandra, dikarenakan kandungan nutrien daun mahoni seperti BETN yang tinggi (Tabel 1) dibandingkan hijauan lainnya.

Tabel 2.

Rerata Kecernaan Bahan Kering, Kecernaan Bahan Organik, Kecernaan Lemak Kasar dan TDN (Total Digestible Nutrients) Berbagai Hijauan secara In Vitro

\begin{tabular}{|c|c|c|c|c|}
\hline & \multicolumn{4}{|c|}{ Parameter } \\
\hline & KcBK & $\mathrm{KcBO}$ & KcLK & TDN \\
\hline & \multicolumn{4}{|l|}{ (1) } \\
\hline $\mathrm{T}$ & $71,32^{\mathrm{b}}$ & $74,26^{\mathrm{b}}$ & $50,14^{\mathrm{d}}$ & $67,07^{b}$ \\
\hline $\mathrm{T}$ & $70,74^{\mathrm{b}}$ & $74,14^{\mathrm{b}}$ & $64,17^{\mathrm{b}}$ & $68,55^{\mathrm{b}}$ \\
\hline $\mathrm{T}$ & $47,95^{\mathrm{d}}$ & $52,89^{\mathrm{d}}$ & $63,63^{\mathrm{b}}$ & $55,40^{\text {cd }}$ \\
\hline $\mathrm{T}$ & $78,40^{\mathrm{a}}$ & $81,30^{\mathrm{a}}$ & $59,97^{\mathrm{c}}$ & $74,80^{\mathrm{a}}$ \\
\hline $\mathrm{T}$ & $55,75^{\mathrm{c}}$ & $60,30^{c}$ & $66,31^{\mathrm{ab}}$ & $57,65^{\mathrm{c}}$ \\
\hline $\mathrm{T}$ & $78,89^{\mathrm{a}}$ & $81,32^{\mathrm{a}}$ & $52,16^{\mathrm{d}}$ & $75,92^{\mathrm{a}}$ \\
\hline $\mathrm{T}$ & $50,40^{\mathrm{cd}}$ & $55,10^{\mathrm{cd}}$ & $43,77^{\mathrm{d}}$ & $51,26^{\mathrm{d}}$ \\
\hline $\mathrm{T}$ & $44,90^{\mathrm{d}}$ & $49,97^{\mathrm{d}}$ & $68,46^{\mathrm{a}}$ & $46,18^{d}$ \\
\hline
\end{tabular}

Superskrip yang berbeda pada kolom yang sama menunjukkan perbedaan yang nyata pada taraf $5 \%(\mathrm{P}<0,05)$

Nilai KcBK pada daun kaliandra rendah dibandingkan dengan daun turi dan daun mahoni. Faktor mempengaruhi adalah kandungan SK pada daun kaliandra tinggi (Tabel 1). Kandungan SK yang tinggi pada pakan akan menyebabkan mikroba rumen sulit untuk mencerna pakan, sehingga nilai KcBK menjadi rendah. Wijayanti et al. (2012) menyatakan bahwa kandungan SK pakan yang tinggi menyebabkan kecernaan menjadi rendah, dikarenakan dinding serat tinggi yang menyebabkan dinding sel menjadi tebal dan sulit untuk ditembus oleh mikroba rumen.

Nilai KcBK pada daun pisang rendah dibandingkan daun turi dan daun mahoni. Faktor yang mempengaruhi adalah kandungan LK pada daun pisang lebih tinggi dibandingkan dengan hijauan lainnya (Tabel 1). Kandungan LK yang tinggi dapat menghambat degradasi pakan oleh mikrobia di dalam rumen, sehingga nilai kecernaan menjadi rendah. Toharmat et al. (2006) menyatakan kandungan lemak yang tinggi menyebabkan nilai kecernaan menjadi rendah, karena daya 
cerna pakan berkorelasi negatif dengan lemak pakan.

\section{Kecernaan Bahan Organik (KcBO)}

Hasil analisis ragam pada berbagai hijauan berbeda nyata $(\mathrm{p}<0,05)$ terhadap nilai KcBO. Nilai KcBO karena hijauan memiliki kandungan nutrisi yang berbedabeda. Abqoriyah et al. (2015) menyatakan kandungan nilai nutrien pada setiap hijauan berbeda, kandungan nutrien akan menurun jika semakin bertambahnya umur tanaman. Uji Duncan menunjukkan nilai KcBO daun turi dan daun mahoni tidak menunjukkan adanya perbedaan. Sedangkan pada daun kaliandra lebih rendah $(\mathrm{p}<0,05)$ dibandingkan dengan $\mathrm{T} 1$, T2, T4, T5 dan T6, tetapi tidak berbeda nyata dengan daun pisang dan daun gamal.

Pengaruh perlakuan nilai $\mathrm{KcBO}$ berbeda-beda, karena jenis hijauan dan kandungan nutrisi yang berbeda-beda. Paramita et al. (2008) menyatakan bahwa faktor yang mempengaruhi nilai kecernaan adalah kandungan kimia maupun fisik bahan pakan dan kondisi ternak seperti kondisi mikrobia dalam rumen. Nilai $\mathrm{KcBO}$ daun turi dan daun mahoni tinggi dibandingkan dengan hijauan lainnya.

Nilai KcBO daun turi dan daun mahoni dipengaruhi oleh kandungan $\mathrm{BO}$ yang tinggi, sehingga daun turi dan daun mahoni mudah dicerna oleh ternak. Dewi et al. (2012) menyatakan bahwa kandungan $\mathrm{BK}$ terdapat abu dan BO tidak terdapat abu, sehingga BO lebih mudah dicerna oleh ternak dan menyebabkan nilai $\mathrm{KcBO}$ menjadi lebih tinggi dibandingkan KcBK. Nilai KcBO pada daun mahoni tinggi dibandingkan daun mangga, daun nangka, daun pisang, daun lamtoro, daun gamal dan daun kaliandra, dikarenakan kandungan nutrisi daun mahoni seperti BETN yang tinggi dibandingkan hijauan lainnya.

Nilai KcBO pada daun kaliandra rendah dibandingkan dengan daun turi dan daun mahoni. Faktor yang mempengaruhi adalah kandungan SK pada daun kaliandra tinggi (Tabel 1). Kandungan SK yang tinggi pada pakan akan menyebabkan mikroba rumen sulit untuk mencerna pakan, sehingga nilai KcBK menjadi rendah yang menyebabkan nilai $\mathrm{KcBO}$ juga rendah, karena jika nilai $\mathrm{KcBK}$ rendah maka nilai KcBO juga rendah. Wijayanti et al. (2012) menyatakan bahwa kandungan SK pakan yang tinggi menyebabkan kecernaan menjadi rendah, dikarenakan dinding serat tinggi yang menyebabkan dinding sel menjadi tebal dan sulit untuk ditembus oleh mikroba rumen.

Nilai KcBO pada daun pisang rendah dibandingkan daun turi dan daun mahoni. Faktor yang mempengaruhi adalah kandungan LK pada daun pisang lebih tinggi dibandingkan dengan hijauan lainnya (Tabel 1). Kandungan LK yang tinggi dapat menghambat degradasi pakan oleh mikrobia di dalam rumen, sehingga nilai kecernaan menjadi rendah. Toharmat et al. (2006) menyatakan kandungan lemak yang tinggi menyebabkan nilai kecernaan menjadi rendah, karena daya cerna pakan berkorelasi negatif dengan lemak pakan.

\section{Kecernaan Lemak Kasar (KcLK)}

Hasil analisis ragam pada berbagai hijauan berbeda nyata $(\mathrm{p}<0,05)$ terhadap nilai KcLK. Nilai KcLK yang berbedabeda dikarenakan jenis hijauan dan kandungan nutrisi yang berbeda-beda pula. Paramita et al. (2008) menyatakan faktor yang mempengaruhi nilai kecernaan adalah jumlah dan kandungan nutrien yang ada di dalam pakan. Uji Duncan menunjukkan nilai KcLK daun kaliandra (T8) dan daun lamtoro (T5) tidak menunjukkan adanya perbedaan. Sedangkan pada daun gamal (T7) lebih rendah $(\mathrm{p}<0,05)$ dibandingkan dengan $\mathrm{T} 2$, T3, T4, T5 dan T8, tetapi tidak berbeda 
nyata dengan daun mangga (T1) dan daun turi (T6).

Daun kaliandra memiliki rata-rata nilai KcLK yang tertinggi dibandingkan dengan hijauan lainnya. Nilai KcLK dipengaruhi oleh kandungan LK pada daun kaliandra yang rendah (Tabel 1), sehingga nilai KcLK tinggi. Farida et al. (2017) menyatakan di dalam lemak terdapat struktur kimia yang mudah dicerna oleh ternak, sehingga jika nilai LK rendah maka nilai KcLK tinggi. Komponen penyusun bahan organik adalah LK dan SK. Kandungan BO pada daun kaliandra tinggi dibandingkan hijauan lainnya (Tabel 1). Tillman et al. (1991) menyatakan komponen penyusun dari BO antara lain SK, protein, lemak, karbohidrat dan BETN, sehingga jika nilai BO pada pakan tinggi, maka nilai KcLK juga akan tinggi. Tetapi, nilai KcBO pada daun kaliandra paling rendah dibandingkan dengan hijauan lainnya. Hal ini dapat disebabkan karena pada daun kaliandra memiliki kandungan SK tinggi menyebabkan nilai $\mathrm{KcBO}$ daun kaliandra rendah. Wajizah et al. (2015) menyatakan bahwa tingginya nilai SK pada bahan pakan akan mempengaruhi nilai kecernaan, karena kecernaan berkorelasi negatif dengan serat pakan.

Nilai kecernaan pakan akan menurun tergantung dari jenis lemaknya, lemak jenuh akan menurunkan KcBK dan $\mathrm{KcBO}$ di dalam rumen. Kandungan kadar lemak di dalam pakan maksimum adalah $5 \%$, sehingga lemak tidak akan mengganggu peroses pencernaan pakan. Wina dan Susana (2013) menyatakan jika lemak jenuh menurunkan nilai kecernaan bahan kering, bahan organik serta NDF (serat) yang ada di dalam rumen ternak, semakin tinggi kadar lemak pada pakan maka semakin rendah nilai kecernaan pakan, asam lemak bebas tidak jenuh akan meracuni mikrobia rumen sehingga menyebabkan bakteri dalam rumen akan menhidrogenasi asam lemak tidak jenuh menjadi asam lemak jenuh.

\section{Total Digestible Nutrients (TDN)}

Hasil analisis ragam pada berbagai hijauan berbeda nyata $(\mathrm{p}<0,05)$ terhadap nilai TDN. Nilai TDN yang berbeda-beda dikarenakan memiliki jenis hijauan dan kandungan nutrisi yang berbeda-beda. Uji Duncan menunjukkan nilai TDN daun turi (T6) dan daun mahoni (T4) tidak menunjukkan adanya perbedaan. Sedangkan pada daun kaliandra (T8) lebih rendah $(\mathrm{p}<0,05)$ dibandingkan dengan $\mathrm{T} 1$, T2, T4, T5 dan T6, tetapi tidak berbeda nyata dengan daun pisang (T3) dan daun gamal (T7).

Daun turi (T6) memiliki nilai TDN lebih tinggi dibandingkan dengan hijauan lainnya (Tabel 2). Hal ini dapat dipengaruhi kandungan nutrien di dalamnya. Kandungan PK, LK dan BETN tinggi, maka nilai TDN juga akan tinggi (Tabel 1). Abqoriyah et al. (2015) menyatakan bahwa pengaruh dari nilai TDN adalah komposisi kimia yang ada di dalamnya tinggi, sehingga nilai TDN nya juga akan tinggi. Nilai TDN adalah total nutrien tercerna yang terdiri dari protein, SK, LK dan BETN, nilai LK dikalikan 2,25. Farida et al. (2017) menyatakan bahwa TDN adalah nutrien sumber energi yang di dalamnya tersusun komponen protein, SK, LK dan BETN, dengan nilai LK dikalikan 2,25.

Daun kaliandra (T8) memiliki nilai TDN yang rendah, hal ini dapat disebabkan nilai KcBO pada daun kaliandra juga rendah. Nilai KcBO yang rendah berpengaruh pada nilai TDN, karena TDN adalah total nutrien tercerna yang terdiri dari protein, SK, LK dan BETN. Kandungan di dalam BO tersusun atas SK, protein, lemak dan BETN. Tillman et al. (1991) menyatakan komponen penyusun dari BO antara lain SK, protein, lemak, karbohidrat dan 
BETN. Sehingga nilai KcBO pada pakan rendah nantinya juga akan mempengaruhi nilai TDN. Mastopan et al. (2015) menyatakan nilai energi dipengaruhi oleh nilai $\mathrm{KcBO}$, kandungan nutrien $(\mathrm{PK}, \mathrm{SK}$, LK dan BETN) yang merupakan BO.

Nilai TDN berbagai hijauan memberikan pengaruh nyata. Hal ini dapat disebabkan karena nilai $\mathrm{KcBO}$ berbagai hijauan juga memberikan pengaruh nyata. Mastopan et al. (2015) menyatakan bahwa TDN adalah total energi yang berasal dari pakan, tinggi rendahnya nilai TDN dapat dipengeruhi dari $\mathrm{KcBO}$ pakan serta kandungan nutrien pakan. Teti et al. (2018) menyatakan bahwa nilai PK pakan dan TDN yang seimbang akan menaikkan nilai kecernaan pakan, karena jika nilai PK pakan dan TDN seimbang akan meningkatkan laju perkembang biakan dan populasi dari mikrobia sehingga mikrobia akan mudah dalam mencerna bahan pakan yang dimakan ternak.

\section{KESIMPULAN}

Berdasarkan hasil analisis nilai kecernaan bahan kering, bahan organik dan lemak kasar dipengaruhi oleh kandungan nutrien dalam bahan pakan, sedangkan nilai TDN berkorelasi dengan nilai kecernaan nutrien dalam bahan pakan. 


\section{DAFTAR PUSTAKA}

Abqoriyah, R. Utomo dan B. Suwigno. 2015. Produktivitas tanaman kaliandra (Calloandra calothysus) sebagai hijauan pakan pada umur pemotongan yang berbeda. Buletin Peternakan. 39 (2) : 103 - 108.

Christiyanto, M. dan A. Subrata. 2005. Perlakuan Fisik dan Biologis pada Limbah Industri Pertanian terhadap Komposisi Serat. Laporan Hasil Penelitian. Lemlit UNDIP. Semarang.

Christiyanto, M., Soejono, M., Utomo, R., Hartadi, H., Widyobroto, B.P., 2005. Konsumsi dan kecernaan nutrien ransum yang berbeda prekrusor protein-energi dengan pakan basal rumput raja pada sapi perah. J. Indon. Trop. Anim. Agric. 30:242-247.

Dewi, N. K., S, Mukodiningsih dan C. I. Sutrisno. 2012. Pengaruh fermentasi kombinasi jerami padi dan jerami jagung denga naras isi rumen kerbau terhadap kecernaan baahn kering dan bahan organic secara in vitro. J. Animal Agriculture. 1 (2) : 134 - 140.

Farida, W. R., A. P. Sari, N. Inayah dan H. A. Nugroho. 2017. Analisis kebutuhan nutrien dan efisiensi penggunaan pakan bubur formulasi pada oposum layang (Petaurus breviceps Waterhouse, 1839). J. Biologi Indonesia. 13 (2) : $305-$ 314.

Hadi, R. F., Kustantinah dan H. Hartadi. 2011. Kecernaan in sacco hijauan leguminosa dan hijauan non leguminosa dalam rumen sapi Peranakan Ongole. Buletin Peternakan. 35 (2) : $79-85$.

Hartadi, H., S. Reksohadiprodjo dan A. D. Tillman. 1993. Tabel Komposisi Pakan untuk Indonesia. Gadjah
Mada University Press, Yogyakarta.

Indrayani., H. Hafid dan D. Agustina. 2015. Kecernaan in vitro silase sampah sayur dan daun gamal menggunakan mikroorganisme rumen kambing. J. Ilmu dan Teknologi Peternakan Tropis. 2 (3) : $17-24$.

Makkar, H. P. S. 2004. Recent Advances in the In Vitro Gas Method for Evaluation of Nutritional Quality of Feed Resources. Animal Production and Health Section, Vienna, Austria.

Mastopan., M. Tafsin dan N. D. Hanafi. 2015. Kecernaan lemak kasar dan TDN (Total digestible nutrients) ransum yang mengandung pelepah daun kelapa sawit dengan perlakuan fisik, kimia, biologis dan kombinasinya pada domba. J. Peternakan Integratif. 3 (1) : 37 45.

Mayulu, H., N.R. Fauziah, M.I. Haris, M. Christiyanto dan Sunarso. 2018. Digestibility value and fermentation level of local feedbased ration for sheep. Animal Production. 20 (2): 95-102.

Paramita, W., W. E. Susanto dan A. B. Yulianto. 2008. Konsumsi dan kecernaan bahan kering dan bahan organik dalam haylase pakan lengkap ternak sapi Pernakan Ongole. J. Media Kedokteran Hewan. 24 (1) : $59-62$.

Purbajanti, E. D., R. D. Soetrisno, E. Hanudin dan S. P. S. Budhi. 2011. Produksi, kualitas dan kecernaan in vitro tanaman rumput benggala (Panicum maximum) pada lahan salin. Buletin Peternakan. 35 (1) : $30-37$.

Teti, N., R. Latvia, I. Hernaman, B. Ayuningsih, D. Ramdani dan 
Siswoyo. 2018. Pengaruh imbangan protein dan energi terhadap kecernaan nutrien ransum domba garut Betina. J. Ilmu dan Teknologi Peternakan. 6 (2) : 97 101.

Tilley, J. M.A. dan R. A. Terry. 1963. A two stage technique for the in vitro digestión of forage crops. J. British Grass Soc. $18: 104-111$.

Tillman, A. D., H. Hartadi, S. Reksohadiprodjo, S. Prawirokusumo dan S. Lebdosoekojo. 1991. Ilmu Makanan Ternak Dasar Cetakan ke 5. Gadjah Mada University Press, Yogyakarta.

Toharmat, T., R. Nursasih, R. Nazilah, N. Hotimah, T. Q. Noerzihad, N. A. Sigit dan Y. Retnani. 2006. Sifat fisik pakan kaya serat dan pengaruhnya terhadap konsumsi dan kecernaan nutrien ransum pada kambing. Media Peternakan. 29 (3) : $146-154$.

Wijayanti, E., F. Wahyono dan Surono. 2012. Kecernaan nutrien dan fermentabilitas pakan komplit dengan level ampas tebu yang berbeda secara in vitro. Anim. Agric. J. 1 (1) : 167 - 179.

Wajizah, S., Sumadi, Y. Usman dan E. Mariana. 2015. Evaluasi nilai nutrisi dan kecernaan in vitro pelepah kelapa sawit (oil palm fronds) yang difermentasi menggunakan Aspergillus niger dengan penambahan sumber karbohidrat yang berbeda. Agripet. $15(1): 13-19$.

Wina, E., dan I. W. R. Susana. 2013. Manfaat lemak terproteksi untuk meningkatkan produksi dan reproduksi ternak ruminansia. J. Wartazo. 23 (4) : 176 - 184. 